\title{
POTENTIAL EFFECT OF TWO DIFFERENT ANAESTHESIA TECHNIQUES ON THE ACTIVATION OF HHV-6 AND HHV-7 INFECTION IN RELATION TO CHANGES IN TOTAL LYMPHOCYTE COUNT AND PERIPHERAL IMMUNE CELL DISTRIBUTION AFTER PROLONGED MICROVASCULAR FREE FLAP SURGERY
}

\author{
Arnis Vilks*\#, Santa Rasa**, Simona Doniṇa***, Modra Murovska**, \\ and Biruta Mamaja ${ }^{\star \star \star \star, \star \star \star \star \star *}$ \\ * Division of Doctoral Studies, Rīga Stradiṇš University, Dzirciema iela 16, Rīga, LV-1007, LATVIA; \\ arnis.vilks@latnet.Iv \\ ** A. Kirhenšteins Institute of Microbiology and Virology, Rīga Stradinš̌ University, Rātsupītes iela 5, Rīga, LV-1069, LATVIA \\ *** Rīga Eastern Clinical University Hospital, Latvian Oncology Centre, Hipokrāta iela 4, Rīga, LV-1039, LATVIA \\ **** Department of Anaesthesiology and Reanimatology, Rīga Stradiṇš University, Dzirciema iela 16, Rīga, LV-1007, LATVIA

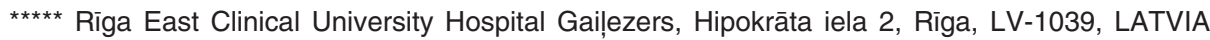 \\ \# Corresponding author
}

Contributed by Modra Murovska

\begin{abstract}
Microvascular free flap surgery is a complex method of wound closure for large wounds. Tissue trauma, surgical stress and general anaesthesia are known immunosuppressors that may exacerbate postoperative infections. Beta-herpesviruses HHV-6 and HHV-7 are immunomodulating viruses highly prevalent in the population of healthy individuals, which can interfere with the function of the host immune system. These viruses can be reactivated in immunosuppressed conditions. The aim of this study was to monitor the potential effects of two different anaesthesia techniques - general anaesthesia (GA) and regional anaesthesia (RA) - on the activation of HHV-6 and HHV-7 infection in relation to changes in the total lymphocyte count and peripheral immune cell distribution after microvascular free flap surgery. We found significant increase in the frequency of active HHV-7 infection after surgery $(\mathrm{p}<0.05)$ in the GA group. In the RA group changes were not significant. The activation of HHV-7 infection was associated with decrease in the total lymphocyte count post-operatively in patients from the GA group. The data of our study show that reconstructive flap surgery under GA is linked with more frequent postoperative Iymphopenia, which is a potential post-operative immunosuppressor that probably triggers the activation of HHV-6 and HHV-7 infection.
\end{abstract}

Key words: anaesthesia, HHV-6, HHV-7, lymphocytes, surgery.

\section{INTRODUCTION}

Microvascular free flap surgery is a complex method of wound closure for large wounds not amenable to linear (primary) closure. It involves the transfer of free tissue (muscle, bone or a combination) to a site of tissue loss where its circulation is restored via microvascular anastomoses. Flaps may be pedicled or free. Pedicled flaps maintain their primary vascular supply while free flaps have their circulation detached and reanastomosed distantly.

The discoveries of human herpesvirus 6 (HHV-6) and human herpesvirus 7 (HHV-7) followed the development of methods for activation and long-term culture of peripheral blood T-lymphocytes. Based on their shared biological properties and nucleotide sequences, HHV-6 and HHV-7 are classified as members of the roseolovirus genus within the betaherpesvirus subfamily. HHV-6 and HHV-7 are very closely related; most HHV-7 protein sequences share $30 \%$ to $60 \%$ amino acid sequence identity with their HHV-6 counterparts (Yamanishi et al., 2007).

Both viruses can productively infect primary CD4+ T-lymphocytes; activation of these cells is required for efficient viral replication. In addition to the cells of the immune 
system, HHV-6 also replicates in many other cells (Braun et al., 1997; Clark, 2000).

In vitro $\mathrm{HHV}-7$ growth is restricted to activated cord blood lymphocytes, purified T lymphocytes, and CD4+ immature SupT1 cells (Black and Pellett, 1999).

The most common outcome of infection with these viruses is not disease, but a lifelong dynamic biological interaction between the virus and host that seldom manifests as disease. However, the infection could become activated in immunosuppressed individuals.

These viruses can be reactivated in immunosuppressed conditions, resulting in the development of direct pathological lesions (Griffiths, 2003). It is also possible that these viruses may indirectly contribute to the activation of other infectious processes by inhibiting the immune system.

Extensive tissue trauma, surgical stress and general anaesthesia are known to suppress a number of immune functions and may exacerbate postoperative infections, affect postoperative healing reactions and increase metastatic rates of tumours (Eggermont et al., 1987; Salo, 1992).

There is emerging interest in evaluating the hypothesis that anaesthetic technique during primary cancer surgery influences the incidence of cancer recurrence or metastasis. Certain anaesthetic agents and techniques, particularly regional anaesthesia, may attenuate metastatic spread and preserve NK T-lymphocyte function (Koltun et al., 1996; Bar-Yosef et al., 2001; Melamed et al., 2003; Shavit et al., 2004).

Growing interest in the effects of different anesthesia techniques on cancer recurrence (O'Rian et al., 2005; Exaddaktylos et al., 2006; Biki et al., 2008) have stimulated us to monitor how prolonged microvascular free flap surgery and different anaesthesia techniques might impact cellular immune response and reactivation of HHV-6 or HHV-7 infection.

The aim of the study was to monitor the potential effects of different anaesthesia techniques on the activation of HHV-6 and HHV-7 infection, in relation to changes in total lymphocyte count and peripheral immune cell distribution after prolonged microvascular free flap surgery.

\section{MATERIALS AND METHODS}

Patients. We studied 58 consecutive patients, mean age $42.20(18-75)$ years (SD = 14.07), who underwent longlasting (average $5.7 \mathrm{~h}$ ) microvascular free flap surgery procedures at the Centre of Plastic and Reconstructive Microsurgery of Latvia. The cohort was established with the approval of the Ethics Committee of the Rīga Stradiňš University and all participants gave their informed consent prior to the examination. Elective microvascular free flap surgery after trauma was chosen to represent a long-lasting major surgical procedure. Surgical intervention was performed at a time remote from the injury, such that influ- ences to the observed changes by trauma are most unlikely. Patients were split into two study groups according to the anaesthesia technique applied — general anaesthesia (GA) group and regional anaesthesia (RA) group.

For $35(60 \%)$ patients general anaesthesia (GA) and for 23 $(40 \%)$ patients regional anaesthesia (RA) was used. Patients were not randomised depending on the anaesthesia method applied, but according to surgical necessity, priority was given to regional anaesthesia. The patients were otherwise healthy with normal cardiac and pulmonary function and not immunocompromised. The patients' characteristics are summarized in Table 1. Types of etiology, and patient numbers are summarised in Table 2.

Anaesthesia methods. All patients were premedicated with oral midazolam $7.5 \mathrm{mg}$. Anaesthesia was induced with propofol $(1.5-2 \mathrm{mg} / \mathrm{kg})$ and fentanyl $(1.5 \mu \mathrm{g} / \mathrm{kg})$. Orotracheal intubation was facilitated with cis-atracurium $(0.2 \mathrm{mg} / \mathrm{kg})$. Normocapnic ventilation was established with capnographic control in order to avoid hypocapnia that leads to vascular

Table 1

PATIENT CHARACTERISTICS

\begin{tabular}{lcc}
\hline & General $(\mathrm{n}=35)$ & Regional $(\mathrm{n}=23)$ \\
\hline Age & $42.31( \pm 13.54)$ & $42.04( \pm 15.26)$ \\
Sex M/F & $22 / 13$ & $8 / 15$ \\
ASA* 1 & $11(34.43 \%)$ & $13(56.52 \%)$ \\
ASA 2 & $21(60 \%)$ & $9(39.13 \%)$ \\
ASA 3 & $3(8.57 \%)$ & $1(4.35 \%)$ \\
Number of previous operations & $2.8( \pm 1.93)$ & $1.78( \pm 1.93)$ \\
after trauma & & \\
$\begin{array}{l}\text { Duration of microvascular free } \\
\text { flap surgery }(\mathrm{h})\end{array}$ & $5.34( \pm 1.44)$ & $5.69( \pm 1.98)$
\end{tabular}

*ASA (American Society of Anesthesiologists) Physical Status Classification System

ASA 1 - a normal healthy patient

ASA 2 - a patient with mild systemic disease

ASA 3 - a patient with severe systemic disease

ASA 4 - a patient with severe systemic disease that is a constant threat to life

ASA 5 - a moribund patient who is not expected to survive without the operation

ASA 6 - a declared brain-dead patient whose organs are being removed for donor purposes

Table 2

TYPES OF ETIOLOGY, AND PATIENT NUMBERS

\begin{tabular}{lcc}
\hline & General $(\mathrm{n}=35)$ & Regional $(\mathrm{n}=23)$ \\
\hline Upper extremity trauma & $4(11.43 \%)$ & $8(34.78 \%)$ \\
Lower extremity trauma & $23(65.71 \%)$ & $12(52.17 \%)$ \\
Extensive surgery (onco) & $7(20.00 \%)$ & $3(13.04 \%)$ \\
Status after scalp injury and & $1(2.86 \%)$ & $0(0 \%)$
\end{tabular}

skull fracture 
resistance and reduces cardiac output and to avoid hypercapnia that leads to sympathetic stimulation.

Additional bolus injection of fentanyl $0.1 \mathrm{mg}$ was given immediately before skin incision. Anaesthesia was maintained with isoflurane (minimal alveolar concentration 0.5-1 according to clinical criteria) and fentanyl $2 \mathrm{mcg} / \mathrm{kg} / \mathrm{h}$. For muscle relaxation during surgery, cis-atracurium $(0.03$ $\mathrm{mg} / \mathrm{kg} / \mathrm{h}$ ) via continuous infusion was used.

Regional anaesthesia was performed with two methods simultaneously (spinal anaesthesia and brachial plexus block - supraclavicular, infraclavicular or axillar aproach). For brachial plexus block, bupivacaine $(0.5 \%-20 \mathrm{ml})$ or levobupivacaine $(0.5 \%-20 \mathrm{ml})$ in combination with lidocaine $(1 \%-20 \mathrm{ml})$ and nerve stimulation was used. For spinal anaesthesia, bupivacaine $(0.5 \%-4 \mathrm{ml})$ and $25 \mu \mathrm{g}$ fentanyl or clonidine $15-30 \mu \mathrm{g}$ as adjuvant at L2-L3 was used. All patients who received RA were sedated with midazolam.

Monitoring consisted of continuous measurements of fivelead electrocardiography (ECG), peripheral oxygen saturation $\left(\mathrm{SaO}_{2}\right)$, fractional inspired oxygen concentration $\left(\mathrm{FiO}_{2}\right)$, fractional expired carbon dioxide concentration $\left(\mathrm{FeCO}_{2}\right)$, minimal alveolar concentration (MAC) of volatile anaesthetic, core and peripheral temperature measurement, central venous pressure (CVP) and non-invasive arterial pressure. The depth of anaesthesia and sedation was monitored with a bispectral index (BIS) monitor. Urine output as indicator of volume status was monitored perioperatively.

Anti-coagulated peripheral blood samples for the detection of latent/persistent or active viral infection were collected from patients before the anaesthesia and reconstructive flap surgery and ten days after the anaesthesia and surgery.

Ethylenediaminetetraacetic acid (EDTA) anti-coagulated peripheral blood samples from patients were collected before surgery and 10 days after surgery. Aliquots of whole blood and blood plasma (after centrifugation) were stored at $-70{ }^{\circ} \mathrm{C}$. Absolute count and peripheral blood CD4+, CD8+, $\mathrm{CD} 38+$, and $\mathrm{CD} 16+$ positive cells were detected by laser flow cytofluorometer (FACSCalibur, USA, Becton Dickinson) using corresponding monoclonal antibodies.

Additional detection of total lymphocyte count on the first day after surgery was performed.
Nested polymerase chain reaction (nPCR) was used for the detection of HHV-6 and HHV-7 sequences in peripheral blood and plasma DNAs. The presence of viral sequences in peripheral blood DNAs was a marker of latent/persistent viral infection and in plasma DNAs - of active viral infection (plasma viremia).

The activation of HHV-6 and HHV-7 infection in patients in relation to postoperative changes in total lymphocyte count and peripheral immune cell distribution after prolonged microvascular free flap surgery under different anaesthesia techniques was assessed. All statistical calculations were performed with commercially available software (IBM SPSS statistics 22.0). Data were analysed using a McNemar's test, ANOVA, or paired sample t-test).

\section{RESULTS}

Before the prolonged microvascular free flap surgery, latent/persistent HHV-6 infection was found in 20 of 58 patients (34.48\%) (14 patients in the GA group and 6 patients in the RA group) and active HHV-6 infection in 4 of 58 patients $(6.90 \%)$ (two patients in the GA group and two patients in the RA group). In 34 patients (58.62\%) (19 patients in GA and 15 patients in RA group) HHV-6 infection was not detected (Fig. 1).

Before the surgery, latent/persistent HHV-7 infection was found in 42 of 58 patients (72.41\%) (26 patients in the GA group and 16 patients in the RA group) and active HHV-7 infection in seven of 58 patients $(12.07 \%)$ (three patients in the GA group and three patients in the RA group).

In nine patients (15.52\%) (six patients in the GA and three patients in the RA groups) HHV-7 infection was not detected (Fig. 2).

Activation of HHV-6 after prolonged microvascular free flap surgery was detected in one patient from the GA group. In the RA group, activation of HHV-6 was not detected (Fig. 3). This difference was not significant $(p>0.05)$.

However, activation of HHV-7 was found in seven patients (six patients in the GA group and one patient in the RA group) (Fig. 4).
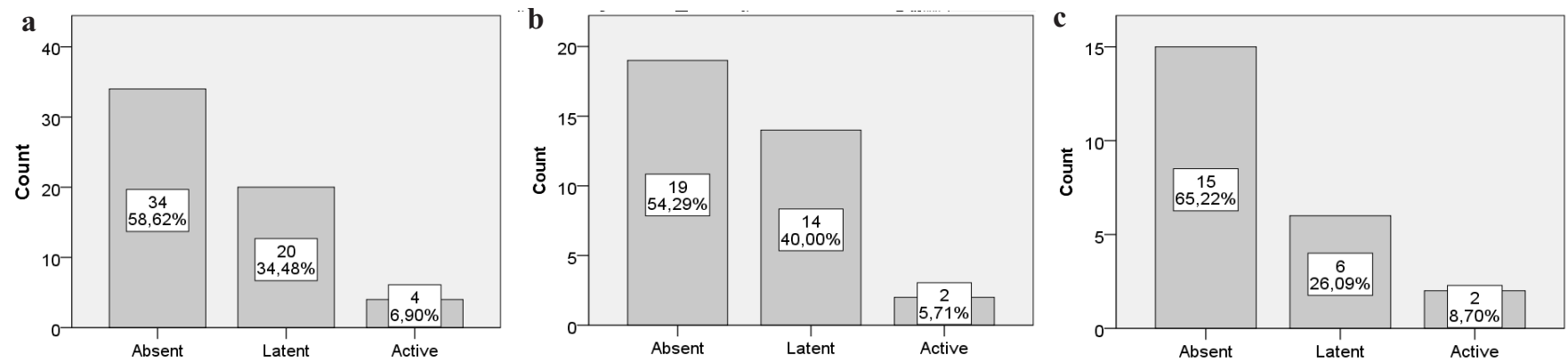

Fig. 1. Frequency of HHV-6 infection before the surgery:

a) in all patients; b) in GA-group patients; c) in RA-group patients. 

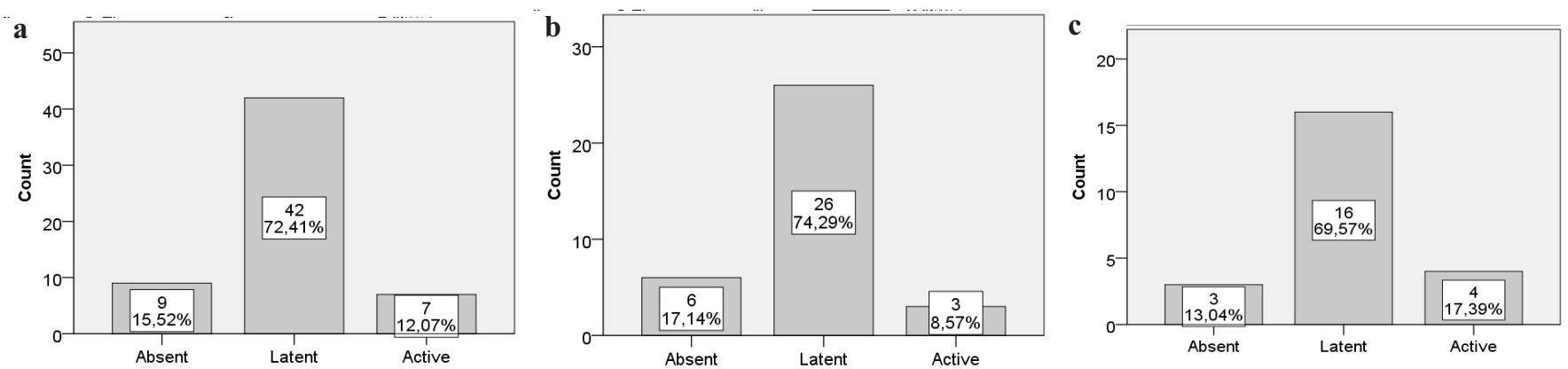

Fig. 2. Frequency of HHV-7 infection before the surgery:

a) in all patients; b) in GA-group patients; c) in RA-group patients.
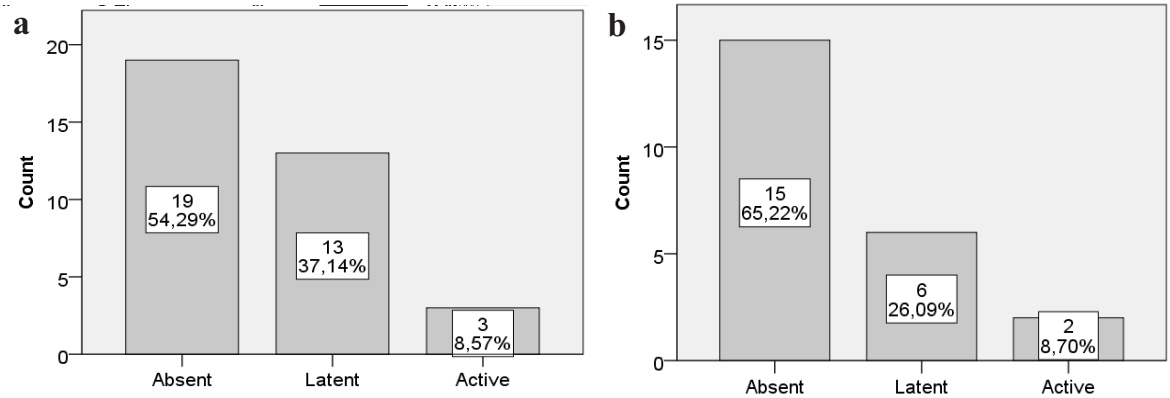

Fig. 3. Frequency of HHV-6 infection after surgery:

a) in GA-group patients; b) in RA-group patients.
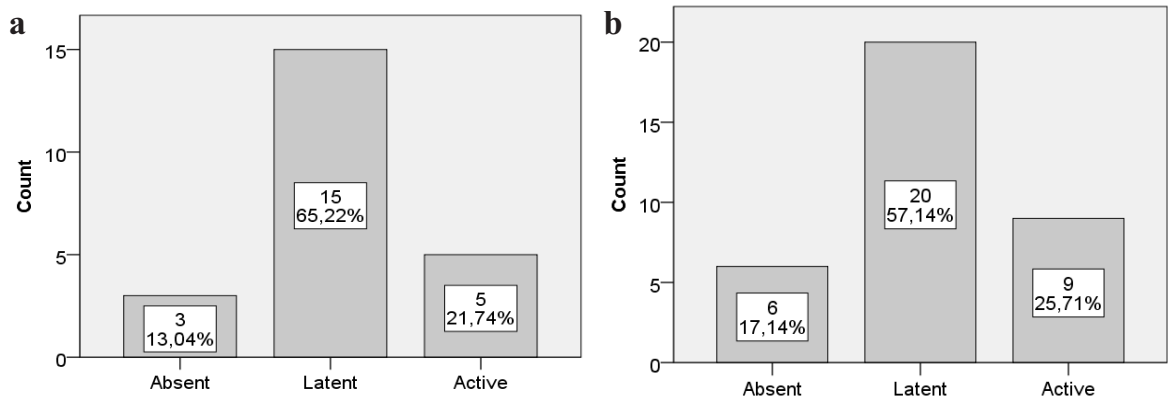

Fig. 4. Frequency of HHV-7 infection after the surgery:

a) in GA-group patients; b) in RA-group patients.

Comparing the frequencies of active and latent HHV-7 infection in GA and RA groups before and after prolonged microvascular free flap surgery, we found significant increase in the frequency of active HHV-7 infection after surgery $(p<0.05)$ in the GA group. The changes were not significant in the RA group.

On the $10^{\text {th }}$ day after surgery, in comparison with the preoperative period, significant decrease $(p<0.05)$ in the number of CD8 positive cells was observed in the GA group, while a significant increase $(p<0.05)$ in the number of CD38 positive cells was observed in the RA group.

Comparing the total number of lymphocytes before and directly after prolonged microvascular free flap surgery, we found significant decrease in the number of lymphocytes in the GA group ( $p=0.01)$, while no significant difference was found in the RA group ( $p=0.25)$.

We found that the decreased number of total lymphocyte count in patients from the GA group was significantly associated with the frequency of activation of HHV-6 or HHV-7 infection $(p=0.04)$. In the RA group $(p=0.50)$, where lymphocyte count postoperatively remained un- changed, an increase in the frequency of active HHV-6 and HHV-7 infection was not observed (Fig. 5).

In the postoperative period in the GA group, number of CD8 + cells decreased significantly $(p<0.05)$ which could lead to large changes in cellular immune response.

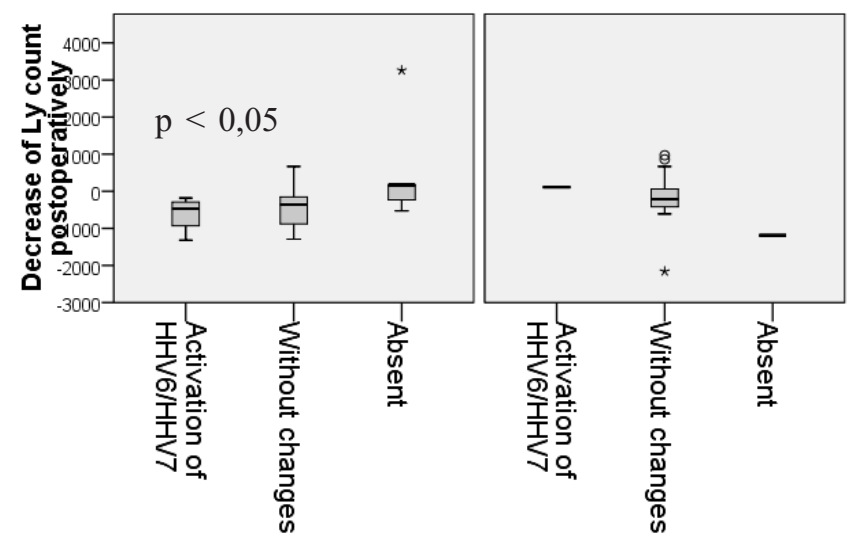

Fig. 5. Association of the decrease in lymphocyte count with frequency of activation of HHV-6/HHV-7 infection:

a) in GA group patients; b) in RA group patients. 
TOTAL LYMPHOCYTE AND LYMPHOCYTE SUBSET COUNTS IN THE GA GROUP BEFORE AND ON THE $10^{\text {TH }}$ DAY AFTER FREE FLAP SURGERY

\begin{tabular}{|c|c|c|c|c|c|c|}
\hline & Lymphocyte & CD4+ & CD8+ & CD16+ & CD38+ & CD4/CD8 \\
\hline Before & $1786.97 \pm 558.45$ & $800.58 \pm 265.57$ & $507.39 \pm 219.07$ & $240.94 \pm 156.22$ & $591.33 \pm 218.72$ & $1.75 \pm 0.72$ \\
\hline After & $1676.67 \pm 569.87$ & $777.79 \pm 294.47$ & $460.18 \pm 235.84^{*}$ & $219.30 \pm 119.94$ & $602.12 \pm 241.13$ & $2.01 \pm 0.95$ \\
\hline
\end{tabular}

The data shown are mean values and $\mathrm{SD}^{*} p<0.05$

Table 4

TOTAL LYMPHOCYTE AND LYMPHOCYTE SUBSET COUNTS IN THE RA GROUP BEFORE AND ON THE $10^{\text {TH }}$ DAY AFTER FREE FLAP SURGERY

\begin{tabular}{l|c|c|c|c|cc}
\hline & Lymphocyte & CD4+ & CD8+ & CD16+ & CD38+ & CD4/CD8 \\
\hline Before & $1670.00 \pm 643.62$ & $821.76 \pm 454.42$ & $430.48 \pm 214.61$ & $231.90 \pm 130.23$ & $502.19 \pm 185.79$ & $1.86 \pm 0.1$ \\
After & $1687.14 \pm 475.82$ & $801.95 \pm 236.92$ & $414.86 \pm 156.26$ & $264.10 \pm 181.94$ & $624.81 \pm 187.60 *$ & $2.01 \pm 0.95$
\end{tabular}

The data shown are mean values and $\mathrm{SD} ; * p<0.05$

Also, a tendency of decrease of $\mathrm{T}$ helper subset (CD4+) count was observed (Table 3 ). In the RA group, a significant increase of activated lymphocyte (CD38+cells) count $(p<0.05)$ was observed (Table 4$)$.

\section{DISCUSSION}

Major surgery suppresses cellular immunity for several days. Humoral immunity remains relatively intact (Shakhar and Ben-Eliyahu, 2003). There is a measurable decrease in the production of cytokines that favour cellular-mediated immunity, such as IL-2, IL-12 and IFN-g, and an increase in the production of cytokines that interfere with cell-mediated immunity, such as IL-10. There is a decrease in the number of circulating NK cells, cytotoxic T lymphocytes, dendritic cells, and T-helper cells. A peak in immunosuppression is thought to occur at day 3 after surgery (Coffey et al., 2003).

Numerous studies (Kurosawa and Kato, 2008) have shown that, alongside with the immunosuppression caused by surgical stress, anaesthetics and analgesic agents commonly used in surgery and in intensive care may directly affect the functions of immune-competent cells.

In our study we observed that the activation of HHV-6 and HHV-7 infection is more pronounced after microvascular free flap surgery in patients of the GA group. Our data are consistent with previous studies suggesting that GA does not suppress the surgical stress response, thus exacerbating postoperative immunosupression (Stevenson et al., 1990). In our study, the specific effector phase of cellular immune response was more affected. It is known that lymphocytopenia, both at baseline and in the postoperative period, is associated with a poor prognosis in cancer patients and that cortisol plays an important role in the immune response (Mussi et al., 2003). The data from previous studies (Toft et al., 2003) indicate that major surgery induces a redistribution of lymphocytes from peripheral blood to lymphatic tis- sue. It is suggested that the endocrine stress response may be of major importance.

The possible interaction of factors under the control of the anaesthetist, such as anaesthetic technique, with factors like cellular immunity, is becoming increasingly clear. For example, there are multiple reports of specific drugs effecting NK cell activity (Snyder and Greenberg 2010).

The potential ability of regional anaesthesia to improve long-term outcome after cancer surgery can be attributed to at least three different mechanisms (Sessler, 2008). First, regional anaesthesia attenuates the immunosuppressive effect of surgery. Neuraxial anaesthesia can inhibit the neuroendocrine stress response, and paravertebral analgesia in humans having breast surgery has also been shown to inhibit this surgical stress response (O'Riain et al., 2005). Secondly, patients who receive regional analgesia have lower opioid requirements (Snyder and Greenberg 2010). Opioids may themselves inhibit cell-mediated immunity and host antitumour defences. Finally, when regional anaesthesia is used in addition to general anaesthesia, the amount of general anaesthetic required during surgery is reduced (Snyder and Greenberg 2010). The data of our study show that reconstructive flap surgery under GA is linked with more frequent postoperative lymphopenia, which is a potential postoperative immunosuppressor that probably triggers the activation of HHV-6 and HHV-7 infection.

\section{REFERENCES}

Bar-Yosef, S., Melamed, R., Page, G. G., Shakhar, G., Shakhar, K., Ben-Eliyahu, S. (2001). Attenuation of the tumor-promoting effect of surgery by spinal blockade in rats. Anesthesiology, 94, 1066-1073.

Biki, B., Mascha, E., Moriarty, D. C., Fitzpatrick, J. M., Sessler, D. I., Buggy, D. J. (2008). Anesthetic technique for radical prostatectomy surgery affects cancer recurrence: A retrospective analysis. Anesthesiology, 109, 180-187.

Black, J. B., Pellett, P. E. (1999). Human herpesvirus 7. Rev. Med. Virol., 9, 245-262. 
Braun, D. K., Dominguez, G., Pellett, P. E. (1997). Human herpesvirus 6. Clin. Microbiol. Rev., 10, 521-567.

Clark, D. A. (2000). Human herpesvirus 6. Rev. Med. Virol., 10 (3), 155-173.

Coffey, J. C., Wang, J. H., Smith, M. J., Bouchier-Hayes, D., Cotter, T.G. (2003). Redmond HP. Excisional surgery for cancer cure: Therapy at a cost. Lancet Oncol., 4, 760-768.

Arvin, A. Campadelli-Fiume, G., Mocarski, E., Moore, P. S., Roizman, B., Whitley, R., Yamanishi, K. (eds.). (2007). Human Herpesviruses: Biology, Therapy, and Immunoprophylaxis. Cambridge: Cambridge University Press. 1408 pp.

Griffiths, P. D. (2003). The indirect effects of virus infections. Rev. Med. Virol., 13, 1-3.

Eggermont, A. M., Steller, E. P., Sugarbaker, P. H. (1987). Laparotomy enhances intraperitoneal tumor growth and abrogates the antitumor effects of interleukin-2 and lymphokine-activated killer cells. Surgery, 102, 71-78.

O’Riain, S. C., Buggy, D. J., Kerin, M. J., Watson, R. W., Moriarty, D. C. (2005). Inhibition of the stress response to breast cancer surgery by regional anesthesia and analgesia does not affect vascular endothelial growth factor and prostaglandin E2. Anesth Analg., 100, 244-249.

Exadaktylos, A. K., Buggy, D. J., Moriarty, D. C., Mascha, E., Sessler, D.,I. (2006). Can anesthetic technique for primary breast cancer surgery affect recurrence or metastasis? Anesthesiology, 105, 660-664.

Kurosawa, S., Kato, M. (2008). Anesthetics, immune cells, and immune responses. J. Anesthesia, 22, 263-277.

Stevenson, G. W., Hall, S. C., Rudnick, S., Seleny, F. L., Stevenson, H. C. (1990). The effect of anaesthetic agents on the human immune response. Anesthesiology, 72, 542-552.

Koltun, W. A., Bloomer, M. M., Tilberg, A. F. (1996). Awake epidural anesthesia is associated with improved natural killer cell cytotoxicity and a reduced stress response. Amer. J. Surg., 171, 68-72.
Melamed, R., Bar-Yosef, S., Shakhar, G., Shakhar, K., Ben-Eliyahu, S. (2003). Suppression of natural killer cell activity and promotion of tumor metastasis by ketamine, thiopental, and halothane, but not by propofol: Mediating mechanisms and prophylactic measures. Anesth. Analg., 97, 1331-1339.

Mussi, C., Angelini, C., Crippa, S., Caprotti, R., Fumagalli, L., Motta, V., Uggeri, F. (2003). Alteration of hypothalamus-pituitary-adrenal glands axis in colorectal cancer patients. Hepatogastroenterology, 50 Suppl. 2, cexxviii-ccxxxi.

O'Riain, S. C., Buggy, D. J., Kerin, M. J., Watson, R. W., Moriarty, D. C. (2005). Inhibition of the stress response to breast cancer surgery by regional anesthesia and analgesia does not affect vascular endothelial growth factor and prostaglandin E2. Anesth. Analg., 100, 244-249.

Salo, M. (1992). Effects on anaesthesia and surgery on the immune response. Acta Anaesth. Scand., 36, 201-220.

Sessler, D. I., Ben-Eliyahu, S., Mascha, E. J., Parat, M. O., Buggy, D. J. (2008). Can regional analgesia reduce the risk of recurrence after breast cancer? Methodology of a multicenter randomized trial. Contemp. Clin. Trials, 29, 517-526.

Shakhar, G., Ben-Eliyahu, S. (2003). Potential prophylactic measures against postoperative immunosuppression: Could they reduce recurrence rates in oncological patients? Ann. Surg. Oncol., 10, 972-992.

Shavit, Y., Ben-Eliyahu, S., Zeidel, A., Beilin, B. (2004). Effects of fentanyl on natural killer cell activity and on resistance to tumour metastasis in rats. Dose and timing study. Neuroimmunomodulation, 11, 255-260.

Snyder, G. L., Greenberg, S. (2010). Effect of anaesthetic technique and other perioperative factors on cancer recurrence. Brit. J. Anaesth., 105, 106-15.

Toft, P., Svendsen, P., Tųnnesen, E., Rasmussen, J. W., Christensen, N. J. (1993). Redistribution of lymphocytes after major surgical stress. Acta Anaesthesiol. Scand., 37 (3), 245-249.

\section{DIVU ATŠK̦IRĪGU ANESTĒZIJAS METOŽU IETEKME UZ HHV-6 UN HHV-7 INFEKCIJAS AKTIVĀCIJU SAISTĪBĀ AR LIMFOCĪTU SKAITU IZMAIN̦ĀM UN PERIFĒRO IMŪNO ŠŪNU SADALI PĒC ILGSTOŠĀM MIKROVASKULĀRĀM BRĪVO LËVERU OPERĀCIJĀM}

Mikrovaskulārā brīvo lēveru kirurğija ir sarežğìta lielu brūču slēgšanas metode. Beta-herpesvīrusi HHV-6 un HHV-7 ir imūnmodulējoši vīrusi, kas bieži konstatējami veseliem iedzīvotājiem. Paši vīrusi reti izraisa saslimšanas pieaugušiem, bet tie var aktivēties situācijās, kad ir nomākta imūnā funkcija. Bieži novērojamā pārejoša subklīniska HHV-6 un HHV-7 aktivācija var radīt nozīmīgus netiešos efektus, kuri, iespējams, ir aktīvas vīrusu infekcijas imūnmodulējošās darbības rezultāts. Latenti persistējoša infekcija var aktivēties imūnsupresijas apstākḷos. Audu trauma, pašas k̦irurğijas radītais stress un vispārējā anestēzija ir zināmi imūno sistēmu nomācoši faktori, kuri var veicināt pēcoperācijas infekcijas. Šajā darbā tika pētīts, kā divas dažādas anestēzijas metodes — vispārējā anestēzija (GA) un reğionālā anestēzija (RA) — ietekmē HHV-6 un HHV-7 infekcijas aktivāciju saistībā ar kopējā limfocītu skaita un perifēro imūnsistēmas šūnu izmaināam pēc ilgstošām mikrovaskulārām brīvo lēveru operācijām. Statistiski ticama HHV-7 infekcijas aktivācija pēc operācijas saistībā ar statistiski ticamu kopējā limfocītu skaita samazinājumu tika konstatēta tikai vispārējās anestēzijas grupā. Pētījuma dati liecina, ka ilgstošas operācijas, izmantojot vispārējo anestēziju, ir saistītas ar biežāku pēcoperācijas limfopēniju, kas ir potenciāls imūnsupresors un, iespējams, veicina HHV-6 un HHV-7 infekcijas aktivāciju. 